\title{
Lipid Peroxidation, Enzymatic and Non-Enzymatic Alterations of DCM-F of Rhizophora mucronata in Diabetic Rats
}

\author{
Gurudeeban Selvaraj*, Satyavani Kaliamurthi and Ramanathan Thirugnansambandan* \\ Centre of Advanced Study in Marine Biology, Faculty of Marine Sciences, Annamalai University, India
}

Submission: September 08, 2017; Published: August 20, 2018

*Corresponding author: Gurudeeban Selvaraj and Ramanathan Thirugnansambandan, Centre of Advanced Study in Marine Biology, Faculty of Marine Sciences, Annamalai University, Parangipettai 608 502, Tamil Nadu, India, Phn: + 914144-243223;

Email: gurudeeb99@gmail.com;drtrcasmb@gmail.com

\begin{abstract}
Oxidative stress is responsible for impairment of $\beta$-cells caused by chronic glucose toxicity. The present study demonstrates dichloromethane fraction (DCM-F) of Rhizophora mucronata mediated fortification against diabetes mellitus induced alterations in antioxidant defense system in the animal model. Single intraperitoneal injection of streptozotocin and nicotinamide was to induce diabetes in rats. $50 \mathrm{mg} / \mathrm{kg}$ of DCM-F was orally treated to diabetic rats for 45 days. At the end of the experiment, blood glucose, lipid hydro-peroxide (LH), plasma enzymatic and nonenzymatic antioxidants were determined. Treatment of DCM-F to the experimental rats notably $(\mathrm{p}<0.01)$ restored blood-glucose, body weight, lipid profile and carbohydrate metabolic enzyme activities. Besides, the intensity of LH increased and CAT, glutathione peroxidase (GPx), GSH, and SOD were considerably decreased in diabetic rats. These unfavourable alterations were inverted to normal in DCM-F treated rats. Moreover, notable results on ceruloplasmin, ascorbic acid, and tocopherol were observed in DCM-F treatment as differenced with diabetic and control. In conclusion, DCM-F of R. mucronata act as antioxidant linked with anti-hyperglycemic and act as a ligand for selected antioxidant receptors.
\end{abstract}

Keywords: Antioxidant; DCM-F; Glutathione peroxidase; Oxidative stress, Rhizophora mucronate

Abbreviations: CAT: Catalase; DCM-F: Dichloromethane Fraction; GPx: Glutathione Peroxidise; GSH: Glutathione; LH: Lipid Hydroperoxide; MDA: Malondialdehyde; PUFA: Polyunsaturated Fatty Acids; SOD: Superoxide Dismutase; TBARS: Thiobarbituric Acid Reactive Substances

\section{Introduction}

Free radicals produced during regular metabolism are removed by way of an efficient scavenging system and the imbalance effects in expanded oxidative strain. Lipid peroxide stages in diabetes are extended in plasma, serum, kidney, lens and in erythrocyte membrane [1]. Significant modifications in lipid metabolism and structural modifications in cell membranes are related to the progress of metabolic disorders [2]. The dysfunction among enzymatic and non-enzymatic oxidation of lipids in vivo is not always absolute [3]. Oxidative pressure has these days been proven accountable, as a minimum in the component, for pancreatic $\beta$-mobile dysfunction due to glucose toxicity. Under hyperglycemia, production of various decreasing sugars, which includes glucose-6-phosphate and fructose, will increase through glycolysis and polyol pathways [4]. During this method, reactive oxygen species (ROS) are produced and cause tissue harm. So, STZ is broadly hired to set off experimental diabetes in animals [5]. DCM-F of Rhizophora mucronata is confirmed anti-hyperglycemic and anti-hyperlipidemic impact on diabetic animals [6]. In the continuation of preceding research, we have appraised the impact of DCM-F on lipid peroxidation and plasma antioxidants in STZ-NAD induced diabetic animals.

\section{Summary}

Body weight, blood glucose, cholesterol, lipid profile, plasma insulin and carbohydrate metabolic enzyme activities of experimental rats were estimated and reported in the previous studies [6]. Figure 1 illustrated the level of LH and TBARS in the plasma of experimental rats. TBARS concentrations were particularly raised in the diabetic rats, distinguished with control and DCM-F treated rats. DCM-F $(50 \mathrm{mg} / \mathrm{kg}$ ) showed a convincing decrease in TBARS level. No consistent changes were found among control and treated rats. Activities of enzymatic antioxidants were clearly giveaway in diabetic rats compared with control and treated rats. Lipid peroxidation is a process enhancing the oxidation of polyunsaturated fatty acids, which causes metabolic disorders, cancer, and cardiovascular diseases. The results of the present study show STZ induced free radicals and increased oxidation of PUFA in the plasma and tissues of diabetic rats. This confirms the previous reports on the 
proficiency of STZ to assist production of free radicals and causes oxidative stress [7]. The increase of reactive oxygen species (ROS) from the reaction of enzymes, metabolism of xenobiotics shows the way to lipid peroxidation with consecutive cell disruption and toxicity [8]. Free radical increases in liver and kidney tissues may accommodate almost absorption of per-oxidize- able fatty acids. DCM-F treatments reduce MDA, an indicator of lipid peroxidation in the tissues of diabetic rats suggesting that the DCM-F have massive anti-oxidative properties. Alkaloids of mangroves have an important role as edible antioxidants for the preclusion of oxidative damages in humans [9].
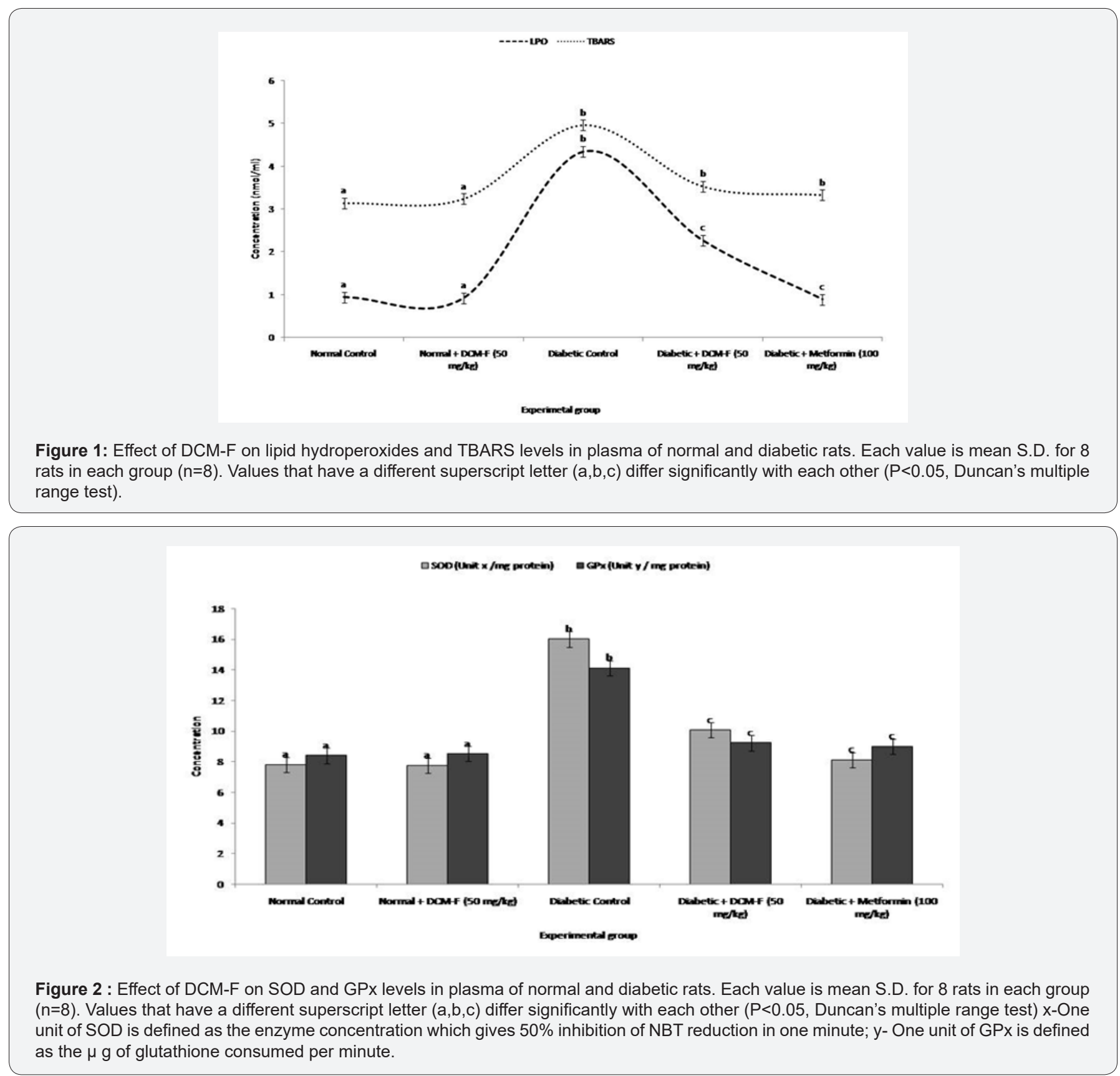

DCM-F treatment explained a rational $(\mathrm{P}<0.05)$ get higher in the actions of superoxide dismutase, catalase (Table 1), and glutathione peroxidise (Figure 2). Notable $(\mathrm{P}<0.05)$ increase in the levels of glutathione, ascorbic acid, $\alpha$-tocopherol and ceruloplasmin in diabetic rats contrasted to control. DCM-F treatment progress to a significant $(\mathrm{P}<0.05)$ increase in the plasma concentrations of glutathione, ascorbic acid, $\alpha$-tocopherol, and ceruloplasmin if compared with diabetic control rats (Table 1). No consistent variations were found among control and treated rats. Catalase and superoxide dismutase plays a major role in the reduction of highly reactive hydroxyl radicals and dismutation of superoxide radicals respectively [10-12]. Glutathione peroxidase detoxifies hydrogen-peroxide into water through the oxidation of reduced glutathione $[13,14]$. The present study results confirm the restored action of enzymatic antioxidants through the treatment of DCM-F. In the 
continuation of lipid peroxidation and formation of hydrogen peroxides are arisen. Inhibition of hydrogen peroxide means that production of hydroxyl radicals is reduced which protects the cells from xenobiotics [15]. In this view, antioxidant alkaloids reduced the oxidative damages through inhibition of free radical formation [16]. Depletion of glutathione may be accompanying to the increased lipid peroxidation in the STZ induced diabetic rats. Previous reports express decreased antioxidant enzyme action enhanced peroxidative sta?tus particularly liver and kidney tissues of diabetic rats $[17,18]$. During peroxidation, $\alpha$-tocopherol reduces lipid hydroperoxides and protects cell damage, while binding to the copper ion ceruloplasmin inhibits lipid peroxidation [19]. Increased utilization as an antioxidant defense system and reduced in the level of glutathione in diabetic rats reduced ascorbic acid [20]. These are supports, DCM-F of Rhizophora mucronata treatment restored antioxidant enzyme action in diabetic rats through detoxification and scavenging of free radicals. Rhizophora mucronata, the mangrove plant isolated DCM-F was studied to control diabetes mellitus to enhance the action of antioxidant enzymes. In conclusion, DCM-F of Rhizophora mucronata act as antioxidant linked with antihyperglycemic effect.

Table 1: Effect of DCM-F on CAT, GSH, Ceroplasmin, Ascorbic acid, and $\alpha$-tocopherol levels in plasma of normal and diabetic rats.

\begin{tabular}{|c|c|c|c|c|c|}
\hline Experiments & Normal Control & $\begin{array}{l}\text { Normal Rat + DCM-F } \\
(50 \mathrm{mg} / \mathrm{kg})\end{array}$ & Diabetic Control & $\begin{array}{c}\text { Diabetic Rat + } \\
\text { DCM-F (50 mg/kg) }\end{array}$ & $\begin{array}{c}\text { Diabetic Rat + } \\
\text { Metformin }(100 \\
\mathrm{mg} / \mathrm{kg})\end{array}$ \\
\hline CAT (unit y/ mg protein) & $0.52 \pm 0.22^{a}$ & $0.57 \pm 0.31^{\mathrm{a}}$ & $3.79 \pm 0.57^{b}$ & $0.68 \pm 0.61^{\mathrm{c}}$ & $0.94 \pm 0.18^{\mathrm{c}}$ \\
\hline GSH (mg/dL) & $93.72 \pm 2.01^{\mathrm{a}}$ & $90.15 \pm 2.11^{\mathrm{a}}$ & $28.51 \pm 1.79^{b}$ & $91.11 \pm 2.10^{\mathrm{c}}$ & $85.2 \pm 2.14^{\mathrm{c}}$ \\
\hline Ceroplasmin (nmol/l) & $1.39 \pm 0.10^{\mathrm{a}}$ & $1.40 \pm 0.11^{\mathrm{a}}$ & $0.85 \pm 0.06^{b}$ & $1.26 \pm 0.07^{\mathrm{c}}$ & $1.32 \pm 0.31^{\mathrm{c}}$ \\
\hline Ascorbic acid (nmol/l) & $0.13 \pm 0.02^{\mathrm{a}}$ & $0.12 \pm 0.01^{\mathrm{a}}$ & $0.05 \pm 0.02^{b}$ & $0.10 \pm 0.02^{\mathrm{c}}$ & $0.11 \pm 0.01^{\mathrm{c}}$ \\
\hline$\alpha$-tocopherol (nmol/l) & $0.05 \pm 0.003^{\mathrm{a}}$ & $0.05 \pm 0.002^{\mathrm{a}}$ & $0.02 \pm 0.001^{\mathrm{b}}$ & $0.04 \pm 0.002^{c}$ & $0.05 \pm 0.001^{\mathrm{c}}$ \\
\hline
\end{tabular}

Each value is mean S.D. for 8 rats in each group $(n=8)$.

Values that have a different superscript letter $(a, b, c)$ differ significantly with each other $(P<0.05$, Duncan's multiple range test).

$z-O n e$ unit of CAT is defined as the $\mu$ mole of hydrogen peroxide consumed per minute.

\section{Acknowledgement}

The authors are grateful to the University Grants Commission, Govt. of India, New Delhi, India (UGC Ref. No.: 39-439/2010) for financial support. The authors extend special thanks to Prof. S. Sengottuvelu and Asst. Prof. V. Lalitha, Nandha College of Pharmacy and Research Institute, TN, India for the support of experimental section and data analysis.

\section{References}

1. Chatziralli IP, Theodossiadis G, Dimitriadis P, et al. (2017) The Effect of Vitamin E on Oxidative Stress Indicated by Serum Malondialdehyde in Insulin-dependent Type 2 Diabetes Mellitus Patients with Retinopathy. Open Ophthalmol J 11:51-58.

2. Obrosova IG, Drel VR, Kumagai AK et al. (2006) Early diabetes-induced biochemical changes in the retina: comparison of rat and mouse models. Diabetologia 49(10): 2525-2533.

3. Khan F, Patterson D, Belch JJF, Hirata K, Lang C (2008) Relationship between peripheral and coronary function using laser Doppler imaging and transthoracic echocardiography. Clin Sci 115(9): 295-300.

4. Fu Z, Gilbert ER, Liu D (2013) Regulation of Insulin Synthesis and Secretion and Pancreatic Beta-Cell Dysfunction in Diabetes. Curr Diabetes Rev 9(1):25-53.

5. Al-Qattan K, Thomson M, Ali M (2008) Garlic (Allium sativum) and ginger (Zingiber officinale) attenuate structural nephropathy progression in streptozotocin-induced diabetic rats. Eur J Clin NutMetab 3(2): 62-71.

6. Selvaraj G, Kaliamurthi S, Thirugnanasambandam R (2017) Effect of dichloromethane fraction of Rhizophora mucronata on carbohydrate, lipid and protein metabolism in type 2 diabetic rats. Integr Obesity diabetes 3: 1-8.
7. Lenzen S (2008) The mechanisms of alloxan- and streptozotocininduced diabetes. Diabetologia 51(2): 216-26.

8. Rajamanickam E, Gurudeeban S, Satyavani K, Ramanathan T (2016) Chemopreventive effect of Acanthus ilicifolius extract on modulating antioxidants, lipid peroxidation and membrane bound enzymes in Diethyl Nitrosamine induced liver carcinogenesis, Int J Cancer Res 12: 1-16.

9. Wang N, Yi WJ, Tan L, Zhang JH, Xu J et al. (2017) Apigenin attenuates streptozotocin-induced pancreatic $\beta$ cell damage by its protective effects on cellular antioxidant defense. In Vitro Cell Dev Biol Anim 53(6): 554-563.

10. Lee HY, Lee JS, Kim HG, Won-Yong Kim, ${ }^{2}$ Seung-Bae Lee, et al. (2017) The ethanol extract of Aquilariae Lignum ameliorates hippocampal oxidative stress in a repeated restraint stress mouse model. BMC Complement Altern Med 17:397.

11. Xi Y, Jiao W, Cao J, Jiang W (2017) Effects of chlorogenic acid on capacity of free radicals scavenging and proteomic changes in postharvest fruit of nectarine. PLoS ONE 12(8): e0182494.

12. Whittaker JW (2012) Non-heme manganese catalase - the 'other' catalase. Arch Biochem Biophys 15; 525(2): 111-120.

13. Sailaja Rao P, Sireesha K, Aparna Y, Sadanandam M (2011) Free Radicals and Tissue Damage: Role of Antioxidants. Free Rad Antiox $1(4): 1-7$.

14. Chatuphonprasert W, Lao-ong T, Jarukamjorn K (2013) Improvement of superoxide dismutase and catalase in streptozotocin -nicotinamideinduced type 2-diabetes in mice by berberine and glibenclamide. Pharmaceutical Biology 52(4): 419-427.

15. Amina A, Hamza AA (2006) Hepatoprotective effects of Hibiscus, rosmarindus and Saliva on azathioprine-induced toxicity in rats. Life Sci 77(3): 266-278. 
16. Patel P, Parikh M, Johari S, Gandhi T (2015) Antihyperglycemic activity of Albizzia lebbeck bark extract in streptozotocin-nicotinamide induced type II diabetes mellitus rats. Ayu 36(3): 335-340.

17. Johansson K, Ahlen K, Rinaldi R, et al. (2007) Microsomal glutathione transferase 1 in anticancer drug resistance. Carcinogenesis 28 (2): 465-470.

18. Li D, Li J, Li H, et al., (2016) Antioxidant properties of repaglinide and its protections against cyclosporine $\mathrm{A}$ - induced renal tubular injury. Iran J Basic Med Sci 19(7): 749- 754

This work is licensed under Creative

Commons Attribution 4.0 License

DOI: 10.19080/JCMAH.2018.07.555701
19. Li J, Liu Y, Zhang P, et al., (2016) Growth inhibition and oxidative damage of Microcystis aeruginosa induced by crude extract of Sagittaria trifolia tubers, J Environ Sci 43: 40-47.

20. Luevano-Contreras C, Garay-Sevilla ME, Chapman-Novakofski K (2012) Role of Dietary Advanced Glycation End Products in Diabetes Mellitus. Evid Based Complemen Altern Med 18 (1): 50-66.

\section{Your next submission with Juniper Publishers} will reach you the below assets

- Quality Editorial service

- Swift Peer Review

- Reprints availability

- E-prints Service

- Manuscript Podcast for convenient understanding

- Global attainment for your research

- Manuscript accessibility in different formats

(Pdf, E-pub, Full Text, Audio)

- Unceasing customer service

Track the below URL for one-step submission https://juniperpublishers.com/online-submission.php 